\title{
Afterword: Evasion of Time: Of Eschaton and Other Illusions
}

\section{Anna M. Agathangelou*}

\section{Introduction}

I am writing this short article and conclusion to the special issue on time and the colonial shortly after Donald Trump's election as the $45^{\text {th }}$ president of the United States. Trump ran on two major mottos: 'We will make America great again' and 'This is our last chance.' In the latter motto, if we are thinking in terms of white male Americans, he may be right. The demographics of the US make it impossible to sustain the fiction that the US empire is white and masculine.

The articulation of a white and masculine US has its genealogy in a fiction of American exceptionalism that, so far, has managed to evade time. This evasion of time, the problematic mystification of time, and the odd notion of progress (making American great again) are set up as core antagonistic ideals in which communities are denigrated (i.e. the Mexicans as rapists), individuals are mocked (US judges of Mexican descent are biased), and modes of living are destroyed. In this vision, 'progress' organises time through the practices of making great across geographic spaces, historical moments, and communities defined (and restricted) by their constructed differences.

The convention of repetition (e.g. the Chinese are smarter than us; Obama is stupid) structure Trump's talk and is supposed to embody a fluidity of progress in the creation and maintenance of the American exceptionalist ethos. However, any genre that does not take seriously the colonial and slavery, and not as 'singular event[s]' but rather as 'singularit[ies] of antiblackness' (Sharpe 2016: 106) accepts unthinkingly the practices of progress used to justify imperialist violence worldwide. This progressive and linearly punctuated narrative is part of an understanding of a particular configuration of power that we have come to understand as empire. In this way, particular figures - rapists, the other, the backward Muslim, the Pocahontas - came to matter in the US election. Simply stated, they are vital to the emergent notion of the 'extinction' of whiteness and the legitimate heirs of white imperialism.

What do we do if racism/sexism fall out of time and no longer register as vital figurations of power in the contemporary formation of neo-liberalism? What happens to deco-

* York University, Toronto-ON, Canada; agathang@yorku.ca. 
lonial theory and decolonial studies around their temporal objects? In my view, writing of any kind, whether in world politics or IR, ought to aid in the critique of the genocidal drive of such propounded American bleached and masculinised exceptionalisms which evade the time(s) of the new transformed state whose re-distributional activities have become marginalised whereas its security and prosperity as well as its military arms have become strengthened.

In this short conclusion, first, I argue that time is pivotal in our understanding of the co-production of the colonial and slavery and the global (i.e. a Kafkaesque 'penal colony'). Cutting through the notion of the social contract as articulated and imagined by Hobbes, I read for a temporal boundedness that itself cannot be resolved without a Christian and religious arrival of heaven on earth (Agamben 2015). Second, I argue that a white destiny of whites, blacks and people of colour is itself a structuring event, demanding an endless deferral and a refusal of a history whose possibility depends on a racialised and slave contract. Such a history becomes possible by constantly orienting the subject of colour, the black thing or the flesh and its hieroglyphics (i.e. 'lacerations, woundings, fissures, tears, scars, openings, ruptures, lesions, rendings, punctures') as Spillers (1987: 67) tells us, toward a post-racial future, all the while articulating blackness as genderless (i.e. the matter of no time upon which violence can happen with impunity). ${ }^{1}$ On the one hand, this flesh is 'violently inscribed with' and yet 'left violently unthought by culture' and outside history's time. This violence 'inscribed on flesh is relegated to a "lower level in the hierarchy of memories"' (Danylevich 2016: 2). Those thus who are historically put outside time cannot make such teleological claims, especially in a colony with a peculiar juridico-technological content, the penal apparatus, the 'machine' or 'installation' which is 'so self-enclosed' that no single part of it could possibly be altered (Kafka 1992 [1914]: 11). And yet, if it was really 'so self-enclosed, surely it would not require the work we have seen over the past year; here, I am thinking of the apparently compulsive reiteration of the catch phrase 'making America great again' and 'this is our last chance.' Third, I conclude by looking at the authors of the special issue and their interventions into a decolonial which is important for 'fugitive justice' (Best and Hartman 2005: 3), taking it to mean a rupture of the structuring events of teleological notions of genocide and violence as part of progress, including the ways neo-liberal policies are being built on sexism and racism that set as its limit the re-investment in the security, prosperity, and military arm of the state and the notion of redistribution for whites only.

\section{Time and temporality: the slave social contract}

Althusius, Spinoza, Locke, and, even more emphatically, Rousseau, commenced and continued to talk about a social contract among independent men, not a Hobbesian slave contract between men and a sovereign master. From contract among free men, all things might emerge, including basic law itself. For the first time, man seemed to be offered a prospect for jumping out of his evolutionary history. 
Man, in concert with his fellows, might change the very structure of social order. (Buchanan 1975: 147-8, cited in Wagner-Tsukamoto 2010: 291)

In the above comment, Buchanan takes social conflict (the 'Hobbesian jungle', 'Hobbesian anarchy') as a way of opening up a conversation about the racialisation and genderisation of the social contract. Much of the conversation on Hobbesian jungle and Hobbesian anarchy itself is marked with certain inscriptions of a notion of time and a history that is a fiction systematically co-produced to keep certain lives secure and others not. For instance, keeping in place the plantation's central position in the neo-liberal market requires a fictional notion of history that masks the ongoing violence (i.e. on black flesh as 'zero degree' and zero time of 'social conceptualization that that does not escape concealment under the brush of discourse' (Spillers 1987: 67) as inherent to the metamorphoses of the Southern agricultural economies into industrialised ones. The transition of the Global North into the economic giant of the world required an equally fictional notion of history about the central position of the colonial within its midst and in the rest of the world.

This evasion of the notion of time, the problematic mystification of time, and its antithesis to eternity are mutually enforced in the relationship between problems of knowledge and problems of social order. There are certain differences in how concerns about time are articulated and embodied in the concepts of the international, such as 'state of nature, 'social contract', 'balance of power', 'containment,' and 'order' (Agathangelou and Killian 2016: 7). A reading of IR scholarship as lacking the desire or as unable to theorise time naturalises or, better yet, evaporates into a narrative which is neither humane nor peaceful when it concerns global governance or reflexive modes of 'scientific analysis' (Hom 2013; Agathangelou and Killian 2016).

But perhaps more important for thinking about the question of time and temporality in relation to the political are the various accounts of violence and sovereignty. Hobbes and Bull both grapple with time, but their understanding of time operates on distinct registers with different embodiments. Dominant readings of IR and dominant readings in world politics empty these registers in the name of articulating a social secular order (albeit theological) at the level of the functioning of the state and the operation of sovereign power considered to be at stake. In that sense, time seems sublated in a social articulated in macro-political terms, and the latter do not have time - they are forever eternal. But that is a function, we may argue, of the subject matter 'world politics.' It is impossible to write about Hobbes, for instance, or Bull's idea of 'order' without considering macro-political questions of the notion of time inscribed on the idea of the sovereign power that itself does not simultaneously embody the progressive secular eschatologically connected to the Kingdom of God, in the 'sense that the first has to disappear when the second is realised' (Agamben 2015: 67). Both Hobbes and Bull are so concerned with this state and order that precipitates the end of time without ever making it part of the questioning.

Of course, in a closer reading of Hobbes, let's say, we see he is dealing with a foundational moment where questions of governance and political form are laid bare. Knowledge 
production, at this time, is directly related to questions of the political. This brings up not just the question of sovereign power, but crucial related questions of what constitutes the public and who has the right to the social slave contract. As Mills tells us the slave contract was what gave Europeans the right to enslave indigenous peoples as well as enslave Africans when this slavery contract was dying in Europe (1997: 24). Central questions include who gets to be the authoritative producer of knowledge, how so, when, and whose witnessing counts as credible. At a simple level, these questions can be answered in terms of a very English notion of class whose time is at the forefront of the body politic and, as feminists argue, of gender and sexuality, and as Fanon argues, race (Grosz 2005; Fanon 1967). But at a more conceptual level, what is at stake is whether a state of nature or a social slave contract or their forms of its structure is constituted at what time and with what possibilities beyond the eschatological.

Hobbes's idea of the public, then, is one that can imagine universal assent; we can even begin to re-think the question of time if we return to the paradox implicit in the Hobbesian theory of violence from which theorists like, for instance, Kant depart. In very schematic terms, we may say sovereign power comes into being in Hobbes as an 'apparatus' for protecting, conserving, improving, and extending life. Hobbes argues that the purpose of the contract is to neutralise the bellum omnium contra omnes and to establish peace. So doing, Hobbes believes, would institute the conditions under which life is no longer brutish, nasty, solitary, poor, and short, but flourishing. But the means to this end is the sovereign person's standing and right to kill. For him, life prolongs and conserves itself by immunising itself, ultimately by admitting a survivable quotient of violent death into the legal and political order it founds. Life preserves itself, in short, by forming a representation of itself (the sovereign person) that, in turn, threatens it with its right to kill. For Hobbes, the right to self-preservation, as well as the security that is the Leviathan's primary goal and justification 'is also what precipitates the end of times' (Agamben 2015: 69; Hobbes 1996 [1651]: 120).

Hobbes also equates the state of nature with no time (and thereby no knowledge, no arts, no society etc.) in his pursuit of and collation of a single temporal referent. However, such an imaginary depends on the eradication or absorption of multiple imagined futures into one time (i.e. setting the time) so that conflicts emerging from such references can be and ought to be contained and controlled.

Anxieties about the multiplicity of imagined and incommensurate (spiritual and religious) futures, fears about the threat of murders and so on, that may emerge from such incommensurable temporalities, along with the desire to solve this problem, push Hobbes to articulate an agreed upon theory of reading. This theory of reading or 'the solution to the problem of knowledge' (Shapin and Schaffer 1985: 332) ought to understand this material and rhetorical anarchy of multiple imagined futures as a problem of the social order to be solved because connecting one's imagination and desire to this multiplicity of futures generates conflict and threatens peace. Paradoxically, it is the co-production of the state through the force of a political time on its subjects and the elimination of those others who still position themselves in this multiplicity that generate the order of time. In an affective manner, Hobbes prepares the ground for a new time and a new political order using the 
Leviathan-State as his example of a firmly closed and controlled, explicitly political present. In this controlled present, sovereignty 'provides for the conditions in which politics can happen at all, let alone peacefully' (Ivison 2015, citing Williams in Martha Nausbaum 2003). We have to read this 'first political question' (Ivison 2015) as having been settled by Hobbes in his introduction of a temporal orientation through his exhaustive use of rhetorical modes to fabulate a theory of reading that again and again reads for an 'a-sociality that exhausts itself in the struggle for survival' (Nyquist 2013: 258), ranging from anaphoric rhetorical negation to 'rigorous subtraction.' His set of rhetorical tools enables him to take his experiment farther and recruit those who would invest resources for the creation of the co-constitution of such a contract with a social order whose primary political imagination is one that recognises time as one organised and ordered toward achieving the political end, the eschaton (i.e., the Kingdom of God on earth). Hobbes is hailed as pivotal in charting a thinking and in organising political action and scientific enterprise as a time question (i.e. the problematic of anarchy/order). Yet are we reading his work haphazardly (Agathangelou and Killian 2016: 8)? If so, what are the implications of easy readings and displacements of the nuanced experiments and fabulations that Hobbes undertakes? Does his utilising certain historical circumstances to invent certain notions of power inform and shape his reading of a certain possibility of history? Should we re-think the relation of our scientific enterprise, indeed literacy itself, as a question of time?

Such co-productions of concepts and notions of time are politically implicated in the politics of colonial domination through enslavement and colonisation. As Walter Johnson points out:

Western concepts like primitiveness, backwardness, and underdevelopment rank areas and people of the world on a seemingly naturalized timeline - their 'present' is our 'past' - and reframe the grubby real-time politics of colonial domination and exploitation as part of an orderly natural process of evolution toward modernity (Johnson 2000: 485).

However, this political philosophy of modernity is riddle with contradictions. Its theological roots in a Judeo-Christian paradigm imagine a state precipitating the end of time, the eschaton, the arrival of a 'messianic banquet,' a freedom from the 'bonds of law' at the end of time for the Christians and whites ONLY.

\section{A colonial and slavery time that never works}

A naturalised timeline depends also on the naturalising of race which itself has a certain economy. Agamben (2015) attempts to reverse the eschatological by arguing that the sovereign, at least until the coming of the end times, is and remains a fiction. In this sense, he argues that it is impossible to understand the relationship of sovereignty and its contingent administration as well as the eschatological signs that inform, shape and organise the whole history. As he says, in the meantime, 'no real unity, no political body is actually possible: the body political can only dissolve itself into a multitude' (Agamben 2015: 49; 
Bussolini 2010). Understanding progress as an economic temporal structure that includes and excludes certain people from the social contract allows us to recognise the indeterminacy of its meaning. For Agamben, this decentered, economic mode of power calls critics to trace the administration of norms, how notions like 'development,' 'progress' and forces of social stasis become drafted into the service of different, often contradictory policies or actions in the civil society to settle conflict and difference. However, time and one's standing in the society are entangled concepts, as Hartman tells us:

Temporal relations can determine the existence or nonexistence of standing. Neither, however, is merely a value-neutral objective datum of life or legal institutions. Like race, time and standing are socially constructed. They are dimensions of power. How human beings use time, how it gets constructed, in Fabian's analysis, is expressive of a worldview, even a cosmology (Hartman 2005: 85).

These incommensurate worldviews (although ostensibly eliminated by Hobbes's social slave contract) are 'not value-neutral positions' (Hartman 2005: 85).

Race as time is socially produced and constituted. Theorists like Hartman (2005), Sexton (2016), Wilderson (2011) and Nanibush (2016) chronicle the shifting interactions between black and indigenous communities and hegemonic modes of temporality imposed onto their being. These theorists argue that progress becomes the central mode of articulating race and temporality. As black and indigenous communities change across locations and times, it becomes clear that the modern project of the state and the national order co-produce notions of temporality and gendered racialisations to secure in place a hegemonic order via monopolising the management of progress, including hierarchising asymmetrically who occupies what in thought. For instance, while the slave's work and his/her life played a pivotal role in the forms of the structures of American national history, the 'slave occupies the position of the unthought' (Hartman 2005: 184-185) which also has implications when Blacks demand 'restitutionary rights' by arguing that slavery was illegal. This demand 'runs counter to norms of accountability and temporality embedded within the law' (Westley 2005: 82). In reparations discourse, standing and time are constructed differently. On the one hand, you have a discourse that argues that with the passage of time people's standing for making claims about race-based injuries is reduced. Others argue that 'temporal restrictions on personal injury claims' are morally defendable as reparations cannot be claimed, especially when the origins of race-based injuries 'are relatively remote in time' (Westley 2005: 85). These constructions of time and standing in a social slave contract evades the time of the brutality that is foundational to the forms of the structures of the nation and evades the time of the unthought in the "official whitesupremacist-historical archive" even when it claims the violence as a past "commodified as something that has been "overcome" (Danylevich 2016: 1).

Dominant notions that collapse temporality as an ontological determination of political subjectivity co-constitute subjects inside and outside the social slave contract. From the perspective of black America, the economic structure of progress requires administrators of a decidedly monochromatic community to disbar black subjects from defining and 
managing progress. From the vantage point of colonial subjects, their attempt to simply restart the history of postcolonial states free of empire via the re-appropriation of governance tools and modernity's rhetorics begets violence. In works of African American theorists, the subject remains a-temporal, barred access to the possibility of progress, or if given access, whiteness constructs and constricts its temporal standing and demands for reparations (Westley 2005). If then slavery remains outside time thereby making it unmournable, can a progressive politics ever confront blackness in the Western world?

By pointing to the differential subject positions, or to use Wilderson's idea of those who are bodies and those who are flesh (Wilderson 2011), or those who register as humans and those who are structurally impossible (Agathangelou 2009), the telos of suffering and mourning relies on the temporal schematic that has historically been activated in the destruction of blackness (in part via fungibility). Barred access to politics writ large and concurrently disbarred from temporality, Blacks, indigenous and colonial subjects face violence unevenly. Such a politics allows for a recognition of subjectivity through a notion of time that allows for standing in a progress narrative for some and not others. It turns the polis or the society into one whose political formulation depends on a linear notion of time that punctures the very category of life by segregating the historical subject (i.e. the human) from matter, the flesh of zero time, robs them of a polity, and turns the flesh into the site upon which force can happen with impunity.

Postcolonial theorist Dipesh Chakrabarty insists that if the present is to direct the future, 'critique has to figure out the now' (2007: 458). To address the question of history and historiography, and thereby the question of time, Chakrabarty speaks of capital's configuration (History 1) and difference (History 2), pushing us to re-think the relationship of the global and the local, the concrete and the universal. For him, History 1 is 'a past posited by capital itself as its precondition', the 'universal and necessary history' whose primary concern is the ongoing circuit-process, whereas History 2 comprises 'narratives and forms of history that do not belong to capital's life process,' things which, although they may contribute to the reproduction of capital, do not necessarily 'lend themselves to capital' (Chakrabarty 2000: 62-63, cited in Walker 2016: 72). This argument does not stand. The division of History into 1 and 2 - where History 1 exists to be interrupted by those whose life does not belong to capital, and History 2 is there to interrupt - presumes a division that is not sustainable (Walker 2016: 73). History 1 and History 2 are rather entangled.

Questions like the national and the imperial, the local and the global, particulars and universals, history and History, the 'transition to capitalist modernity' can and ought to be understood from the vantage point of a time that is not teleological, one that takes seriously time and standing. One way of understanding this is to think through with Fanon's challenge of both Marxian categories of time when he concerns himself with history and labour and 'psychoanalytic readings of culture' (Marriott 2012: 57). Marxian notions of history and labour (i.e. time as exchange) highlight the tensions between class and race and the teleological notions of freedom that come with work. Fanon's work single-handedly challenges the notions of modernity (i.e. capital) and difference (Eurocentrism vs. the rest) that Chakrabarty speaks of. 
Fanon writes in stark contrast to the notion of going back to a pre-colonial world or recovering the past. Challenging the teleology of a history that recognises time as exchange only is central to any project that also takes seriously the sedimentation of the middle class and its alienation. Speaking in and of Black Skin/White Masks, Fanon tells us:

This book is a clinical study. Those who recognize themselves in it, I think, will have made a step forward. I seriously hope to persuade my brother, whether black or white, to tear off with all his strength the shameful livery put together by centuries of incomprehension. The architecture of this work is rooted in the temporal. Every human problem must be considered from the standpoint of time. Ideally, the present will always contribute to the building of the future. And it is for my own time that I should live. The future should be an edifice supported by living men. This structure is connected to the present to the extent that I consider the present in terms of something to be exceeded (Fanon 1967: 5-6).

It is only from the standpoint of time that Fanon speaks, acknowledging the 'centuries of incomphrehension' which make notions of history and the present itself incomprehensible as they co-produce fictions about race and mystical pasts (Fanon 1967: 7). Fanon says, 'The body of history does not determine a single one of my actions' (Fanon 1967: 180).

Pushing for a struggle that is not appealing to either History 1 or History 2 is of utmost importance for re-thinking and forming radical political capacities to undertake a project that ruptures the time of capital, colonisation, and enslavement including the destruction of the ecology. Reason or respect, as Fanon would remind us, cannot alter reality. History or any knowledge cannot alter reality. It is not a question; nor is it about Marxsim or idealistic analysis. Rather, the issue is struggle:

I do not carry innocence to the point of believing that appeals to reason or to respect for human dignity can alter reality. For the $\mathrm{Ne}$ gro who works on a sugar plantation in Le Robert, there is only one solution: to fight.... I call middle-class a closed society in which life has no taste, in which the air is tainted, in which ideas and men are corrupt. And I think that a man who takes a stand against this death is in a sense a revolutionary (Fanon 1967: 224-2).

Distinguishing between the time of labour and the middle class, Fanon allows us to see that this difference is pivotal when thinking about change. Basically, the time of the middle-class is problematic, 'a time that is nonexistent, for in trying to undo what has happened (colonialism) in the name of an alienated past, the colonial bourgeois forbids all discovery, and as a result of this identification with a dead other [and a dead order], he is himself already dead' (Marriott 2012: 71). 
So this move to find one's social validation in any History, whether 1 or 2 , is not radical at all. It depends on a fictional alienation of a dead past. What is thus pivotal is the re-invention of the struggle in time. Articulations of a struggle that ruptures neurotic and exchange notions of time (i.e. wanting to recover the past, or afraid to make a leap, all in the name of security) are and ought to be at the forefront of any struggle and any kind of reading that does not evade time.

\section{Decolonial possibilities}

In the contributions of Aparna Devare and Hitomi Koyama to this special issue, we read how historicism has been turned into a source of social critique. Myths and mythologies do not subscribe to a linear notion of time but dissolve singularity. Jyotiba Phule turns historicism into a social critique. By drawing and using myths, Devare tells us, Phule is able to highlight that a teleological transition is always incomplete. The event itself is a configuration of a signification assemblage according to which phenomena can be computed within the frameworks of modernity, in either the universal or the particular, the local and the global. Thus, events such as the colonial or slavery are irreparable moments of the modern condition, whose effects we are still living through.

In her contribution, El-Malik reads Senghor's Negritude as a 'crevice in history'. For her, his work is a struggle to keep alive moments of decolonisation the moment they were fragmented. Senghor challenges this truncation by speaking of a culture that ruptures the dichotomisation of the particular and the universal, articulating all the while a new form of specificity that embodies a multiplicity of worlds. Khadija El Alaoui intervenes and ruptures a historiography that presumes a past/present/future and reminds us that the 'past' is always open informing and shaping the way struggle unfolds in the present. For her, the cry of poets comes in the 'mm-hmms' of students and the songs of the poets remembering simultaneously the colonial wound and the possibilities for mobilisation and solidarity.

In the co-authored work of Narendran Kumarakulasingam and Mvuselelo Ngcoya and the article by João Urt one finds moments of decolonial ecological embodiments that challenge linear homogeneous temporalities of indigenism and historical expropriations. Rather, their invention is one of challenging the dichotomisations that come in the form of us and them, secular and spiritual, past and present.

The work of Angela Iranzo Dosdad and Manu Samnotra positions us squarely in the production of knowledge sciences to problematise the dominant notions that co-produced the technological/developmentalist projects and thinking of the postcolonial order. Both works embody a move to provincialise Europe by articulating a notion of the political that breaks from historiographies and dominant progress projects that imprison us rather than free us.

All these works bring us back to what it means to think struggle and time. Like others who challenge dominant temporal divisions of the world (the locals, the natives, etc. vs the global capitalists) (Scott 2008), the authors in this special edition articulate schematics and alternative histories and narratives as the way to resist the hegemonising, histo- 
riographic and flattening material capital forms of life that take linearity and the time of modernity at its word.

In The Wretched of the Earth and Black Skin/White Masks, Fanon emphasises present action derived from perception, and the muscular tonicity of the colonised (Fanon 1967; Fanon 2008 [1952]). He points to a relationship between time and action that strains against the dialectical, ontological, and linear approaches in which he is situated (Agathangelou 2015; Marriott 2011), for instance, his break with and devastating critique of dialectical thinking in Black Skin/White Masks, and his insight that dialectics pose a limit to thinking present action and becoming not already contained in structures of history. A violent force and a 'real leap' (Fanon 1967: 229) allow for a politics to emerge through creativity and action augmented by the force of time, inciting the present to exceed its rigid determinations.

Slavery, colonialism, settler colonialism, the stuff of world politics and the objects of analysis of indigenous theorists, theorists of slavery and postcolonial theorists persist as a series of events in time, while inflecting the present and operating as a force that precipitates new events opening to indeterminacy (Fanon 1967). Interrogations of time from such a vantage point, then, point to temporal disjunctions that come with narration, in conflicting or silenced histories, or as symptoms of processes of global capital. In narration, time is said to be out of joint, as writing out of signification provides a critical and temporal lag in identity - personal, sovereign, and international. Political subjects require moments in which to live - not just conceptions of time - and moments in which politics can happen.

But how does the co-production of 'time' and 'political order' become imagined and possible? What is the time of critiques of colonialism and imaginings of a decolonial future (i.e. Fanon's) when those critiques and imaginings are 'staked on the refusal of racial subjectivity' (Marriott 2014: 717) and thus call for a new world order? What if the readings of critiques of colonialism and imaginings of a decolonial future are inventions, the real leaps of our times?

In Islands of Decolonial Love Leanne Simpson explores the lives of Indigenous Peoples and communities, especially her own Nishnaabeg nation. Her characters are from the reserves, from cities and small towns, from bars and curling rinks, canoes and community centres, from doctors' offices and pickup trucks; they struggle with the challenge of pairing the desire to live loving and present lives with the constant struggle to simply survive the historical and ongoing brutal violences of racism and colonialism. Drawing on multiple languages and histories of her people, she states that the temporality of rupture is the present. To challenge and rupture dominant and neurotic notions of time and ideas of life and death inscribed with, as Fanon says, the colonial bourgeoisie is to participate in regeneration. Simpson tells us:

I am repeatedly told that I cannot be angry if I want transformative change - that the expression of anger and rage as emotions are wrong, misguided, and counter-productive to the movement. The underlying message in such statements is that we, as Indigenous and 
Black peoples, are not allowed to express a full range of human emotions. We are encouraged to suppress responses that are not deemed palatable or respectable to settler society (Simpson 2014).

The settler colonial system failed to fulfill the promised dreams of liberty and equality as spelled out in the slave and colonial contract. Thus, protest becomes the creative regenerative moment for a world otherwise to be realised here and in the now. It is no longer a secret that the progressive time of liberal democracy defines some lives as valued and worthy and others as nonexistent. A struggle to rupture that kind of a future is a fight and a struggle for life and for the present. The time is too late or too early for this struggle, for the combat breath (Agathangelou 2011, citing Fanon 1967) to rupture a universal and progress narrative of capital and difference that wants to forget its systematic 'primitive accumulations,' even when its 'historicisation throws us back on the very limit of historicity itself’ (Walker 2016: 102).

This special issue is a reminder that the decolonial dance is not finished. The poets and the dancers are still with us and remind us that to take the real leap is to regenerate, to continue to remember the 'historical,' all the while embracing an open-ended possibility whose futurity does not transform the fact of colonial, slave, and postcolonial death into a mode through which to reproduce a deadly eschatological structure. Rather, going into the source allows for an endless creation and regeneration. In 'Dreams bite', Audre Lorde muses: 'I shall love again/ When I am obsolete' (Lorde 1977: 55).

\section{Notes}

1 Frank Wilderson (2010: 136) stretches this notion of flesh as a ' $\mathrm{g}$ ] ratuitous violence [that] relegates the Slave to the taxonomy, the list of things. That is, it reduces the Slave to an object. Motherhood, fatherhood, and gender differentiations can only be sustained in the taxonomy of subjects'.

\section{References}

Agamben, Giorgio. 2015. Stasis. Stanford, CA: Stanford University Press.

Agathangelou, Anna M. 2009. 'Necro- (neo) Colonisations and Economies of Blackness: Of Slaughters, "Accidents," "Disasters" and Captive Flesh' In Shiela Nair and Shampa Biswas (eds), International Relations and States of Exception: Margins, Peripheries and Excluded Bodies. New York: Routledge, pp. 186-209

. 2011. 'Bodies to the Slaughter: Slavery, Reconstruction, Fanon's Combat Breath, and Wrestling for Life'. Somatechnics Journal 1(1): 209-248

2014. 'Wither Anarchy?: Harvesting the "Global" Bio-tech Body, Indian Markets and Biomedical Technologies'. In Maximilian Mayer et al. (eds), The Global Politics of Science and Technology - Vol. 2. Berlin: Springer-Verlag, pp. 179-204

Agathangelou, Anna M and Kyle D Killian (eds) 2016. Time, Temporality and Violence in International Relations: (De) Fatalizing the Present, Forging Radical Alternatives. London: Routledge.

Buchanan, James. 1975. The Limits of Liberty: Between Anarchy and Leviathan. Chicago: Chicago University Press. 
Bull, Headley. [1977] 2002. The Anarchical Society: A Study of Order in World Politics. New York: Columbia University Press.

Bussolini, Jean. 2010. 'What is Dispositive?' Foucault Studies 10: 85-107.

Chakrabarty, Dipesh. 2000. Provincializing Europe: Postcolonial Thought and Historical Difference. Princeton: Princeton University Press.

2004. 'Where is the Now?' Critical Inquiry, 30(2): 458-62.

Danylevich, Theodora. 2016. 'Beyond Thinking: Black Flesh as Meat Patties and The End of eating Everything'. Rhizomes 29. DOI: 10.20415/rhiz/029.e15

Fabian, Johannes. 1983. Time and the Other: How Anthropology Makes Its Object, New York: Columbia University Press.

Fanon, Frantz. 1967. The Wretched of the Earth, New York: Grove Press. . [1952] 2008. Black Skin/White Masks, London, UK: Pluto Press.

Grosz, Elizabeth. 2005. The Nick of Time: Politics, Evolution, and the Untimely, Durham: Duke University Press.

Hartman, Saidiya V. 1997. Scenes of Subjection: Terror, Slavery, and Self-Making in Nineteenth Century America. New York: Oxford University Press.

Hartman, Saidiya V and Frank B. Wilderson, III. 2003. 'The Position of the Unthought'. Qui Parle 13 (2): 183-201.

Hobbes, Thomas. 1969. The Elements of Law Natural and Politic, $2^{\text {nd }}$ ed., Ferdinand Tönnies (ed), New York: Barnes and Noble.

1983. De Cive. Howard Warrender (ed), Vol. 2 of the Clarendon edition of the Philosophical Works of Thomas Hobbes. Oxford: Oxford University Press

[1651] 1996. Leviathan. Richard Tuck (ed). Cambridge: Cambridge University Press.

[1642] 1998. On the Citizen (Originally published as De Cive), trans. Richard Tuck and Michael Silverthorne (eds), Cambridge: Cambridge University Press.

Hom, Andrew. 2008. Time and International Relations Theory. Master of Arts Thesis, University of Kansas. . 2013. Reckoning Ruin: International Relations Theorising and the Problem of Time. Ph.D. Dissertation, Aberystwyth University.

Ivison, Duncan. 2015. 'Indigenous Peoples, Injustice and Global Politics'. In Barbara Buckinx, Jonathan Trejo-Mathys and Timothy Waligore (eds), Domination and Global Political Justice: Conceptual, Historical and Institutional Perspectives. New York: Routledge,pp. 206-23.

Johnson, Walter. 2000. 'Possible Pasts: Some Speculations on Time, Temporality and the History of Atlantic Slavery'. American Studies 45 (4): 485-99.

Kafka, Franz [1914] 1992. 'In the Penal Colony'. In Malcolm Pasley (trans.), The Metamorphosis and Other Stories. New York: Penguin, pp. 111-13.

Lorde, Audre. 1997. 'Dreams Bite.... In The Collected Poems of Audre Lorde. New York: W. W. Norton, pp. 55. Marriott, David. 2011. 'Whither Fanon?' Textual Practice 25(1): 33-69.

Mbembe, Achille. 2001. On The Postcolony. Berkeley: University of California Press.

Nussbaum Martha. 2003. 'Tragedy and Justice Bernard Williams remembered'. Available at:

http://new.bostonreview.net/archives/BR28.5/nussbaum.html [Accessed 27 October 2016]. 
Nyquist, Mary. 2013. Arbitrary Rule: Slavery, Tyranny, and the Power of Life and Death, Chicago: University of Chicago Press.

Schapin, Steven and and Simon Schaffer. 2011. Leviathan and the Air-Pump:Hobbes, Boyle, and the Experimental Life. Princeton, NJ: Princeton University Press.

Scott, David. 2008. 'Tragedy's Time: Postemancipation Futures Past and Present'. In Rita Felski (ed), Rethinking Tragedy. Baltimore, MD: John Hopkins University Press, pp. 199-218.

Sexton, Jared. 2016. 'The Social Life of Social Death'. In Anna M Agathangelou and Kyle D. Killian (eds). Time, Temporality and Violence in International Relations: (De) Fatalizing the Present, Forging Radical Alternatives. London: Routledge, pp. 61-75.

Simpson, Leanne. 2013. Islands of Decolonial Love. Winnipeg: ARP Press.

. 2014. 'Indict the System: Indigenous \& Black Connected Resistance'. Available at:

http://leannesimpson.ca/indict-the-system-indigenous-black-connected-resistance/ [Accessed 27 October 2016].

Spillers, Hortense. 1987. 'Mama’s Baby, Papa’s Maybe: An American Grammar Book'. Diacritics 17.2: 64-81.

Wagner-Tsukamoto, Sigmund. 2013. The Economics of Paradise: On the Onset of Modernity in Antiquity. New York: Palgrave Macmillan Walker, Gavin. 2016. The Sublime Perversion of Capital: Marxist Theory and the Politics of History in Modern Japan. Durham, NC: Duke University Press.

Westley, Robert. 2005. 'The Accursed Share: Genealogy, Temporality, and the Problem of Value in Black Reparations Discourse'. Representations 92 (1): 81-116

Wilderson, III, Frank B. 2010. Red, White \& Black: Cinema and the Structure of U.S.

Antagonisms. Durham, NC: Duke University Press.

\section{About the author}

Anna M. Agathangelou is an associate professor in Political Science at York University, Toronto and former fellow of the Program of Science, Technology and Society, J.F. Kennedy School of Government, Harvard. She is co-editor of Time, Temporality and Violence in International Relations: (De) Fatalizing the Present, Forging Radical Alternatives (Routledge, 2016) (with Kyle D. Killian), co-editor of Arab Revolutions and World Transformations with Nevzat Soguk (Routledge 2013), the co-author of Transforming World Politics: From Empire to Multiple Worlds (with L.H.M. Ling) (Routledge 2009), the author of Global Political Economy of Sex: Desire, Violence and Insecurity in Mediterranean Nation-States (Palgrave 2004).

Received on 15 November 2016, and approved for publication on 16 November 2016.

\section{(cc) BY-NC} https://creativecommons.org/licenses/by-nc/4.0/ 